\title{
Analysis Of Legal Protection Of Patients In Health Services In General Hospital Sari Mulia Banjarmasin
}

\author{
${ }^{1}$ Fakhruddin Razy, ${ }^{2} \mathrm{M}$. Mahendra Abdi \\ Razyf1463@gmail.com \\ Sari Mulia University, Banjarmasin Indonesia
}

\begin{abstract}
Background research many specific cases of the patient as well as a lawsuit involving a home ill as a result of the patient not satisfied or even harmed by the health services provided by hospitals are an indication that legal awareness is increasing. This study aims to assess the extent of the legal protection of patients in health care is implemented by health workers in hospitals Sari Mulia Banjarmasin. With juridical methods of sociological researchers examined the legal protection of patients by looking at the extent of the patient's rights met by health care workers and hospitals. The results showed that the legal protection of patients in health care in RSU Sari Mulia Banjarmasin is good. Conclusion Factors that hinder and support consist of internal factors and external factors which include communication, information, legal awareness, hospital facilities, the working environment as well as the attitude of the patient.
\end{abstract}

Keywords: Protection of Patients, Hospitals, Factor Internal, External Factors

\section{Introduction}

In order to improve the quality of life and adequate health care, the government and private sector to provide health care institution called the hospital. Hospital which is a personal health service delivery in the plenary that provides inpatient, outpatient and emergency services provided for the benefit of society in terms of improved quality of life. Advances in science and technology in the health sector has grown rapidly and is supported by an increasingly sophisticated health facilities, these developments also influence professional services in the field of health over time is growing as well.

How various treatments are developed so that the result is also getting bigger, and the possibility to make the greater mistake. The number of specific cases of the patients as well as a lawsuit involving a hospital as a result of the patient not satisfied or even harmed by the health services provided by hospitals are an indication that legal awareness is increasing. People are increasingly aware of the rules of law, getting to know their rights and obligations and more knowledgeable voices demanding that the law plays a role in health. It also causes people (patients) would no longer take for granted the treatments performed by medical side. Patients want to know how the medical procedure done so that they would not suffer losses due to errors and medical negligence.

The emergence of the relationship between patients, doctors and patients to the hospital can be because the patient is very urgent to get help. In these circumstances the hospitals, 
especially the doctor immediately do what is called zaakwaarneming, ie where a voluntarily without receiving orders representing other people's business interests represented by those who can solve these interests, in addition to the relationship between doctor and patient, the role of home pain in applying the legal protection of patients is also very necessary. In the medical world is growing, the role of the hospital is very important in supporting the health of the community. Advance or retreat of the hospital will be largely determined by the success of those who work in hospitals, in this case the doctors, nurses and people who are in that place. The hospital is expected to be able to understand its consumers as a whole and be able to apply the protection of patients as consumers of health services. In health care, hospitals also have to pay attention to professional ethics of health professionals who work in hospitals are concerned. However, professionals working in hospitals in providing professionally decision is independent. Such decisions should be based on awareness, responsibility and high moral accordance with the ethics of their respective professions.

Medicals given trust by the patient, and employed in hospitals must pay attention to the merits of the action and always be careful in carrying out medical procedures, with order for protection of the patient can be realized and from the medical measures do not cover the possibility of an error or omission. Errors or omissions committed health workers in carrying out professional duties can be fatal to both the body and soul of the patient, and this of course is very detrimental to the patient.

Patients as consumers, that means "every user or users of goods and or services either own interest and the interests of others". Patients already felt happy when her written piece of paper. From recipes implicitly have demonstrated their recognition of the authority of science which is owned by the concerned doctor. Authorities science arise and complete confidence of patients is due to ignorance of the patient regarding what he suffered, and what drugs are needed, and here only a doctor is out, coupled with an atmosphere that is completely closed and secretive that includes positions that doctor guaranteed by codes of medical ethics. Such notch was growing stronger because coupled with the scarcity factor is the amount of energy health / doctor, so it is a monopoly position for her in providing health care services so that the protection of patients is less assured.

o see the extent of the legal protection afforded by a medical institution or hospital to the patient / consumer health course we not only hear from other people or just read from books alone, for it is here the researcher must examine it directly to a medical institution / home certain pain and here researchers chose General Hospital Sari Mulia Banjarmasin as a place to study on consumer protection health, whether legal protection against health consumer is already being implemented in accordance with the Health Act that exist today or still need to be improved and what only the enabling and constraining the legal protection of the health of consumers.

From the description set forth above, the issue of legal protection of patients as consumers of services in health care, it contains issues that are very complex and attractive so as to encourage researchers to examine more deeply about legal protection for patients who are growing and developing in the medical world, especially in the context of health care.

\section{Methods}

In this study used research methods as follows: 
1. Survey The survey is a technique mangkaji study aimed at social or institutional situation in order to find the incidence, distribution, relationships and interrelationships constructs relative of research, such as the values, perceptions, aspirations, motivation and individual behavior. This method was chosen based on the grounds that the use of this method with regard to interview techniques in factual information gathering stage. This is in accordance with the opinion of Fred N. Kerlinger which states that:

"Research survey of the best uses of the personal interview as the primary method of gathering information. Factual information collected in the survey include the so-called sociological data ".

2. Observations Observations Studies is a research technique by means of observing the object of research in the form of social situations related to the purpose of research. This method was chosen because researchers can directly observe myself all the attitudes and behavior of health workers and patients in providing health services. The instruments used in this observational study are: 1. Anecdotal records also called a history of behavior are the notes made about the behavior-behavior researcher outstanding that are considered important by researchers periodically 2 . Note that the researcher does not record all kinds of special events but only at certain times only. 3. Check the list which is a list that contains the names of the subject and the factors that is going to be investigated, which is intended to systematize the observation records, the tool allows researchers obtain convincing data in other fields 4 . Rating Scale is recorded according to the symptom level, this tool used to obtain an overview of the state of the subjects according to their level.

3. Documentation Documentation method is a technique of research for the purpose of describing the objective, systematic and

qualitative any written material or movies (documents) are not prepared for their demand for a. This document can be seen as a resource that can answer questions posed to him, although the document can only react as far as what is written, but much can be interpreted from that paper, it was not explicit but implicit. Specification used in this research is in the description of the analysis, is a study that aims not merely to express or describe the suitability of legislation in the reality of people's lives alone, but also to understand the implementation of laws and regulations are based on the rule of law to understand what the background of the implementation.

\section{Results}

Researchers broadly concluded that there are five (5) guarantees the right of patients to be met by the hospital that the legal protection of patients as consumers of services in health care can be met: 1. Guarantee To Get Information On Current Health Care Provided 2. Top Security Security, Convenience and Safety Health Care Top Top 3. guarantees of Equality in Health Care guarantee Top 4. Freedom of Choice Nursing Care Top Top 5. guarantee Freedom for the Demanding rights of disadvantaged After concluding guarantee these rights investigator in conducting research using interviews to patients, physicians / health care workers and hospital officials, as planned from the beginning the researchers conducted interviews to 9 (nine) informant as a resource and key informants namely to three (3) doctors (key informants), 1 (one ) hospital officials), two (2) nurses and three (3) Patient / family housed in RSU Sari Mulia Banjarmasin. From the research, then the results of research made in the form of matrix as follows: 
Table1. Matrix 1 : Assurance of Information on Health Services

\begin{tabular}{|c|c|c|c|}
\hline $\begin{array}{l}\text { Name of } \\
\text { the } \\
\text { Informant }\end{array}$ & $\begin{array}{l}\text { Answer Substance } \\
\text { Research Subjects }\end{array}$ & $\begin{array}{l}\text { Meaning } \\
\text { Of Themes }\end{array}$ & Implications \\
\hline \multirow[t]{3}{*}{$\begin{array}{l}\text { "U" } \\
\text { (Doctor) }\end{array}$} & $\begin{array}{l}\text { • "Regarding confidentiality } \\
\text { I do not know". } \\
\text { • "Regarding the order I } \\
\text { read from text or banner } \\
\text { that reads the order of the } \\
\text { hospital" }\end{array}$ & $\begin{array}{l}- \text { Providing } \\
\text { information } \\
\text { about } \\
\text { hospital } \\
\text { rules }\end{array}$ & $\begin{array}{l}\text { health has been } \\
\text { carried out by a } \\
\text { doctor / health } \\
\text { personnel and } \\
\text { acceptable to } \\
\text { patients }\end{array}$ \\
\hline & $\begin{array}{l}\text { • "Yes, I explained about } \\
\text { the patient condition } \\
\text { information" } \\
\text { • "I think that patients } \\
\text { understand what I } \\
\text { explained" } \\
\text { • "on confidentiality had to } \\
\text { be done" • "Yes, patients } \\
\text { are given information about } \\
\text { the rules" }\end{array}$ & $\begin{array}{l}\cdot \text { Provision } \\
\text { of Medical } \\
\text { Information } \\
\text { - A } \\
\text { description } \\
\text { of the } \\
\text { condition of } \\
\text { the patient's } \\
\text { disease } \\
\text { Medical } \\
\text { Information } \\
\text { Confidential } \\
\text { ity rules }\end{array}$ & $\begin{array}{l}\text { Good, } \\
\text { Guarantees of } \\
\text { medical } \\
\text { information in } \\
\text { the health service } \\
\text { has been carried } \\
\text { out by a doctor / } \\
\text { health worker }\end{array}$ \\
\hline & $\begin{array}{l}\text { - "Definitely, the doctor } \\
\text { explained about the } \\
\text { information to the patient } \\
\text { and there Inform concent" • } \\
\text { "I think that the patient } \\
\text { understands, doctors usually } \\
\text { ask her education what, if } \\
\text { the patient does not } \\
\text { understand about what is } \\
\text { described then the doctor } \\
\text { will try to explain it back in } \\
\text { a language that can be } \\
\text { understood" • "the patient's } \\
\text { condition should be kept } \\
\text { confidential because it is a } \\
\text { code of ethics". • Yes, } \\
\text { dikasi information but } \\
\text { usually affixed in each } \\
\text { corner of the room in }\end{array}$ & $\begin{array}{l}\cdot \text { Provision } \\
\text { of medical } \\
\text { information } \\
\text { - Providing } \\
\text { informed } \\
\text { concent to } \\
\text { patients } \\
\text { Explanation } \\
\text { of the } \\
\text { patient's } \\
\text { disease } \\
\text { condition } \\
\text { medical } \\
\text { confidentiali } \\
\text { ty as the } \\
\text { code of } \\
\text { conduct } \\
\text { physicians } \\
\text { Information } \\
\text { disciplinary } \\
\text { hospital }\end{array}$ & $\begin{array}{l}\text { Well, the } \\
\text { guarantee of } \\
\text { information, } \\
\text { confidentiality } \\
\text { and disease } \\
\text { prevention are } \\
\text { fully } \\
\text { implemented by } \\
\text { a physician / } \\
\text { health personnel } \\
\text { at the time given } \\
\text { health care }\end{array}$ \\
\hline
\end{tabular}


Table 2. Matrix 2: Guarantees for Security, Comfort and Safety for Health Services

\begin{tabular}{|c|c|c|c|}
\hline $\begin{array}{l}\text { Name of } \\
\text { the }\end{array}$ & $\begin{array}{l}\text { Answer Substance } \\
\text { Research Subjects }\end{array}$ & $\begin{array}{l}\text { Meaning Of } \\
\text { Themes }\end{array}$ & Implications \\
\hline \multirow[t]{2}{*}{$\begin{array}{l}\text { "V" } \\
\text { (Officials } \\
\text { Hospital) }\end{array}$} & $\begin{array}{l}\text { - "after the patient } \\
\text { comes directly to the } \\
\text { patient's doctor to } \\
\text { explain such } \\
\text { information to the } \\
\text { patient and } \\
\text { consideration of alleged } \\
\text { actions to be taken are } \\
\text { also delivered directly } \\
\text { to the patient and will } \\
\text { also inform concent. } \\
\text { doctor explained well } \\
\text { about the patient's } \\
\text { condition and I think } \\
\text { that patients understand }\end{array}$ & $\begin{array}{l}\text { - Medical } \bullet \text { the } \\
\text { provision of } \\
\text { information to } \\
\text { patients giving } \\
\text { informed concent } \\
\text { - explanation of } \\
\text { the patient's } \\
\text { disease condition } \\
\text { - medical } \\
\text { confidentiality } \\
\text { code of ethics as a } \\
\text { doctor } • \text { provision } \\
\text { of information }\end{array}$ & $\begin{array}{l}\text { Well, the guarantee of } \\
\text { information, } \\
\text { confidentiality and disease } \\
\text { prevention are fully } \\
\text { implemented by a } \\
\text { physician / health } \\
\text { personnel at the time given } \\
\text { health care }\end{array}$ \\
\hline & $\begin{array}{l}\text { - regarding the } \\
\text { confidentiality of the } \\
\text { patient's illness I think it } \\
\text { - is a necessity and it is } \\
\text { related to the code of } \\
\text { conduct which is owned } \\
\text { by a doctor. } \\
\text { the informationg about } \\
\text { the order of these things } \\
\text { have been stated clearly } \\
\text { in every corner of the } \\
\text { hospital that is the } \\
\text { presence information } \\
\text { board for anyone who } \\
\text { comes to the hospital } \\
\text { and can be read by } \\
\text { visitors to the hospital, } \\
\text { for example the rules } \\
\text { concerning children } \\
\text { who are still minors are } \\
\text { not allowed to enter the } \\
\text { room the patient or the } \\
\text { patient visiting hours } \\
\text { but it also if there are } \\
\text { families of patients who } \\
\text { stay there will be a } \\
\text { letter of permission to } \\
\text { stay and it will be } \\
\text { informed }\end{array}$ & $\begin{array}{l}\text { - disciplinary } \\
\text { hospital infectious } \\
\text { disease prevention } \\
\text { to patients }\end{array}$ & \\
\hline
\end{tabular}




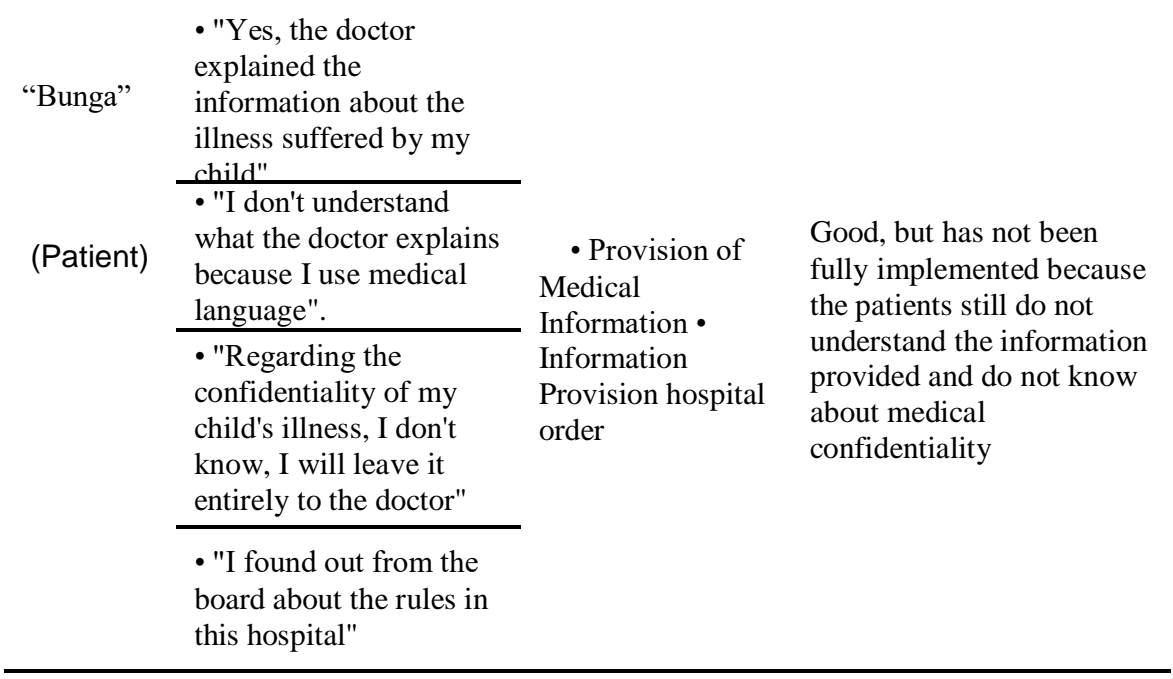

Judging from the matrix can be explained that one of the most important factors and to see the extent of their legal protection in a hospital is the fulfillment of the rights of patients, one of which is the right to obtain information. The right to information is processed in evolution, in line with the development of human rights. The core of the right to information is the right of patients to obtain information from doctors, on matters relating to health, in the event of the relationship between doctor and patient, is a good thing when the doctor informs the patient about his health.

\section{Conclusion}

Based on the results of research and analysis, as noted above, it can be concluded as follows: The legal protection of patients as consumers of services in health care at the General Hospital of Sari Mulia has been good this can be evidenced by: a) fulfillment of the information needed patient about his illness in when given the health service; b) The implementation of security, comfort and safety when given health services c) Patients treated equally when given health care by a physician / health personnel; d) The consent of the patient in the delivery of health services as a realization of the freedom of health professionals and patients choose treatments class; e) suggestion service box, a complaint directly to the doctor / nurse and their field service for complaints of patients.

\section{References}

[1] Az.Nasution, 2011, the Consumer Protection Law, Jakarta:

[2] Bahder Johan, 2005, the Health Law Accountability Doctor, PT. Rineka Cipta, Jakarta

[3] Bastian Suryono, Indra, 2011, the Dispute Resolution Health, Jakarta: Salemba Medika.

[4] Fred. N. Kerlinger, 1990. Principles of Research Bihavioral, R. Translator Landung Simatupang, Gajah Mada University Press, Yogyakarta, p. 663. 
[5] Hanafi, M.Yusuf and Amir, Amri, 1987, Medical Ethics and Health Law, Jakarta: EGC.

[6] Noeng Muhadjir, 1996. Qualitative Research Methodology, Edition III, Rekesarasin, Yogyakarta,

[7] Soejami, 1992, Some Problems of Law and Medical, Bandung, Citra Aditya

\section{CONSTITUTION :}

[1] Undang-undang Nomor 36 Tahun 2009 Tentang Kesehatan

[2] Undang-undang Nomor 29 Tahun 2004 Tentang Praktik Kedokteran

[3] Undang-undang Nomor 44 Tahun 2009 Tentang Rumah Sakit

[4] Undang-undang Nomor 8 Tahun 1999 Tentang Perlindungan Konsumen 